\title{
A 10-year follow up of publishing ethics in China: what is new and what is unchanged
}

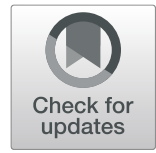

Katrina A. Bramstedt ${ }^{1,2^{*}}$ (D) and Jun $\mathrm{Xu}^{3}$

\begin{abstract}
Background: Organ donation and transplantation in China are ethically complex due to questionable informed consent and the use of prisoners as donors. Publishing works from China can be problematic. The objective of this study was to perform a 10-year follow up on Chinese journals active in donation and transplant publishing regarding the evolution of their publishing guidelines.

Methods: Eleven Chinese journals were analyzed for 7 properties: (1) ethics committee approval; (2) procedure consent; (3) publishing consent; (4) authorship criteria; (5) conflict of interest; (6) duplicate publication; and (7) data integrity. Results were compared with our 2008 study data. Additionally, open access status, impact factor, and MEDLINE-indexing were explored.
\end{abstract}

Results: Most journals heightened the ethical requirements for publishing, compared to the results of 2008. All 11 now require their published manuscripts to have data integrity. Ten of 11 require ethics committee approval and informed consent for the publication of research studies, whereas in the original study only 2 journals evidenced these requirements. Nine of 11 have criteria for authorship, require conflict of interest disclosure, and forbid duplicate publishing. None of the journals have a policy to exclude data that was obtained from unethical organ donation practices. Nine of 11 journals are MEDLINE-indexed but only 2 are open-access.

Conclusions: Most journals have improved their general ethical publishing requirements but none address unethical organ donation practices.

Keywords: Publishing, Research ethics, Informed consent, China, Research integrity, Organ donation

\section{Background}

Does a decade change much for transplant publishing ethics in China? In 2008, the publishing practices of numerous medical journals which are active in the field of solid organ transplantation were explored [1]. Transplantation in China is controversial due to unethical practices such as the use of prisoners as organ donors and lack of informed consent [2]. Scholarly journals which adhere to standard ethical guidelines such as those from the International Committee of Medical Journal Editors [3] forbid publishing of articles which lack ethical assurances such as informed consent and research ethics committee review, but as shown a decade

\footnotetext{
*Correspondence: txbioethics@yahoo.com

${ }^{1}$ Luxembourg Agency for Research Integrity (LARI), 6, avenue des

Hauts-Fourneaux, L-4362 Esch-sur-Alzette, Luxembourg

${ }^{2}$ Bond University Medical Program, University Drive, Gold Coast, Queensland,

Australia

Full list of author information is available at the end of the article
}

ago [1], many journals from China were willing to publish works lacking these ethical considerations. The current research explores the 11 Chinese journals from the original study, to investigate their current publishing guidelines, in light of more than a decade of continued controversy about questionable Chinese transplant practices, as well as China's known high rates of plagiarism [4] and duplicate publication [1,4].

\section{Methods}

Our original study [1] identified 11 journals ${ }^{1}$ from China that had published articles by authors implicated in the Matas-Kilgour investigation of unethical organ donation practices [2]. In December 2018, these 11 journals identified prior were re-analyzed for the same 7 properties: (1) human research

\footnotetext{
${ }^{1}$ In the original study, 12 Chinese journals were identified but only 11 were active (one ceased publication).
} 
studies require approval from the research ethics board; (2) research subjects required to provide informed consent; (3) informed consent required from patients with descriptive or identifying case information; (4) journal specifies authorship criteria; (5) conflict of interest/funding disclosure required; (6) duplicate publication prohibited; (7) article contents must be truthful/data must have integrity. As with our original study, these properties were derived by reading the journal's website and instructions for authors [JX-pages in Chinese; KB-pages in English and post-translation pages]. Translation from Chinese to English was performed by the co-author of this article [JX]. The results (Table 1) were compared with the data from the 2008 study. Additionally, the impact factor of each journal was searched using the 2018 Edition of the Journal Citation Reports [5]. The National Library of Medicine online catalog [6] was searched to identify MEDLINE indexing. The journal websites were reviewed for their open-access status.

\section{Results}

As shown in Table 1, all 11 journals now require that manuscript data have integrity (e.g., no fabrication, falsification, deception), whereas in the original study only 3 journals evidenced this requirement. Ten of 11 (90.9\%) journals require research ethics committee approval and informed consent for the publication of research studies, whereas in the original study only 2 journals evidenced these requirements. Nine of 11 (81.8\%) journals have criteria for authorship, require conflict of interest disclosure, and forbid duplicate publishing practices. Of note, in the original study, ACTA Academiae Medicinae Sinicae, required conflict of interest disclosure and forbid duplicate publication; however, their revised author guidelines omit these requirements.

Table 1 Journal Guidelines $(2008,2018)$

\begin{tabular}{|c|c|c|c|c|c|c|c|}
\hline Journal & $\begin{array}{l}\text { Ethics } \\
\text { approval }\end{array}$ & $\begin{array}{l}\text { Research } \\
\text { informed } \\
\text { consent }\end{array}$ & $\begin{array}{l}\text { Publication } \\
\text { informed } \\
\text { consent }\end{array}$ & $\begin{array}{l}\text { Authorship } \\
\text { criteria }\end{array}$ & $\mathrm{COI}$ & $\begin{array}{l}\text { No } \\
\text { duplicate } \\
\text { publishing }\end{array}$ & $\begin{array}{l}\text { Data } \\
\text { integrity }\end{array}$ \\
\hline $\begin{array}{l}\text { ACTA Academiae Medicinae Sinicae } \\
\text { http://www.actacams.com/CN/column/column32.shtml }\end{array}$ & No, yes & No, yes & No, yes & No, yes & $\begin{array}{l}\text { Yes, } \\
\text { no }\end{array}$ & Yes, no & Yes, yes \\
\hline $\begin{array}{l}\text { Chinese Critical Care Medicine http://cmaes.medline.org.cn/Login/ } \\
\text { tgxz.aspx }\end{array}$ & $U$, yes & $U$, yes & $U$, no & $U$, yes & $\begin{array}{l}U, \\
\text { yes }\end{array}$ & $U$, yes & $U$, yes \\
\hline $\begin{array}{l}\text { Chinese Journal of Hepatology http://cmaes.medline.org.cn/Login/ } \\
\text { tgxz.aspx }\end{array}$ & No, yes & No, yes & No, no & No, yes & $\begin{array}{l}\text { Yes, } \\
\text { yes }\end{array}$ & Yes, yes & Yes, yes \\
\hline $\begin{array}{l}\text { Chinese Journal of Integrated } \\
\text { Traditional and } \\
\text { Western Medicine } \rightarrow \text { new title: Chinese Journal of Integrative Medicine } \\
\text { http://www.springer.com/cda/content/document/cda_- } \\
\text { downloaddocument/2014lnstructions+for+Authors.pdf?SGWID=0- } \\
\text { 0-45-1053737-p161470158 }\end{array}$ & No, yes & No, yes & No, yes & No, yes & $\begin{array}{l}\text { No, } \\
\text { yes }\end{array}$ & No, yes & Yes, yes \\
\hline $\begin{array}{l}\text { Chinese Journal of Surgery http://cmaes.medline.org.cn/Login/tgxz. } \\
\text { aspx }\end{array}$ & No, yes & No, yes & No, no & Yes, yes & $\begin{array}{l}\text { Yes, } \\
\text { yes }\end{array}$ & Yes, yes & No, yes \\
\hline $\begin{array}{l}\text { Chinese Medical Journal } \\
\text { http://cmaes.medline.org.cn/Login/tgxz.aspx }\end{array}$ & Yes, yes & Yes, yes & Yes, no & Yes, yes & $\begin{array}{l}\text { Yes, } \\
\text { yes }\end{array}$ & Yes, yes & No, yes \\
\hline $\begin{array}{l}\text { Hepatobiliary and Pancreatic Diseases } \\
\text { International https://www.elsevier.com/journals/hepatobiliary-and- } \\
\text { pancreatic-diseases-international/1499-3872/guide-for-authors }\end{array}$ & Yes, yes & Yes, yes & No, yes & Yes, yes & $\begin{array}{l}\text { Yes, } \\
\text { yes }\end{array}$ & Yes, yes & No, yes \\
\hline $\begin{array}{l}\text { Journal of Huazhong University of Science and Technology } \\
\text { [Medical Sciences] } \rightarrow \text { new title: Current Medical Science http://www. } \\
\text { springer.com/cda/content/document/cda_downloaddocument/ } \\
\text { INSTRUCTIONS++FOR+AUTHORS_11596.pdf?SGWID=0-0-45-4455 } \\
\text { 98-p173620803 }\end{array}$ & No, yes & No, yes & No, no & No, no & $\begin{array}{l}\text { No, } \\
\text { yes }\end{array}$ & Yes, yes & No, yes \\
\hline $\begin{array}{l}\text { National Journal of Andrology http://www.nkxb.cbpt.cnki.net/WKB2/ } \\
\text { WebPublication/wkTextContent.aspx?navigationContentID=98b4 } \\
\text { 7930-5e45-4f40-8d24-47949651169e\&mid=nkxb }\end{array}$ & No, no & No, no & No, no & No, no & $\begin{array}{l}\text { No, } \\
\text { no }\end{array}$ & No, no & No, yes \\
\hline $\begin{array}{l}\text { National Medical Journal of China } \\
\text { http://cmaes.medline.org.cn/Login/tgxz.aspx }\end{array}$ & No, yes & No, yes & No, no & Yes, yes & $\begin{array}{l}\text { No, } \\
\text { yes }\end{array}$ & Yes, yes & No, yes \\
\hline $\begin{array}{l}\text { World Journal of Gastroenterology }{ }^{\dagger} \\
\text { https://www.wjgnet.com/bpg/Gerlnfo/288 }\end{array}$ & No, yes & No, yes & No, yes & Yes, yes & $\begin{array}{l}\text { Yes, } \\
\text { yes }\end{array}$ & No, yes & No, yes \\
\hline
\end{tabular}

$\mathrm{COI}$ conflict of interest/funding disclosure required

$\checkmark$ Unable to obtain instructions for authors from journal in 2008

tOwned by Baishideng Publishing Group Inc. (registered in USA) with its subsidiary, Beijing Baishideng BioMed Scientific Co., Limited (Production Center and Editorial Office) located in China 
Only 4 of 11 (36.4\%) journals require patient consent for the publication of descriptive case studies and/or their associated images. Notably, in the original study, only Chinese Medical Journal stated this requirement, but it has been omitted from their current author guidelines.

National Journal of Andrology performed consistently poor in terms of publication ethics in both the original study and this re-analysis. In 2008, National Journal of Andrology scored 0 of 7 with regard to ethical publishing requirements. In 2018, the journal improved in only one area: they now specifically require manuscript data to have integrity [7]. This journal is MEDLINE-indexed and publishes a variety of works including basic research, clinical research, review articles, clinical experience exchanges, and case reports.

Access to journals can be limited by language and cost. In this study (Table 2), only 2 of 11 (18.2\%) journals are published as open-access, providing free availability to scientists and the lay public. The remaining 9 journals allow free access to the article abstracts but limit access to the full-text articles using paywalls. Five of 11 (45.5\%) journals publish their articles in English, while the remainder publish their abstracts/summaries and/or tables of contents in English. Nine of 11 (81.8\%) journals are currently indexed in MEDLINE, facilitating easy access to their English abstracts.

With regard to impact factor, 6 of 11 (54.6\%) remain without an impact factor a decade after our initial study. Three of 12 (25\%) developed an impact factor as they had none in the prior study. One journal's impact factor rose greatly ( 0.561 to 1.596 , Chinese Medical Journal), while another fell slightly (3.318 to 3.300 , World Journal of Gastroenterology).

\section{Discussion}

Ease of access (in terms of cost and language) can facilitate the readership of a journal. Specifically, open access [free] and English-language publishing give articles greater visibility, as well as readability. This said journals which are read should have high ethical standards. Additionally, impact factor and indexing are assumed by many to be measures of journal quality. MEDLINE requires their indexed journals to satisfy several "critical elements" including "demonstrating statements indicating adherence to ethical guidelines; evidence that

Table 2 Impact factor, indexing, language, access

\begin{tabular}{|c|c|c|c|c|}
\hline Journal & $\begin{array}{l}\text { Impact factor } \\
\left(2005^{*}, 2018\right)\end{array}$ & $\begin{array}{l}\text { MEDLINE- } \\
\text { indexed }\end{array}$ & Language & $\begin{array}{l}\text { Open-access or } \\
\text { paywall }\end{array}$ \\
\hline ACTA Academiae Medicinae Sinicae & None, none & Yes & $\begin{array}{l}\text { Articles in Chinese; abstracts and table } \\
\text { of contents in Chinese and English }\end{array}$ & $\begin{array}{l}\text { Free abstract; } \\
\text { paywalled } \\
\text { articles }\end{array}$ \\
\hline Chinese Critical Care Medicine & None, none & No & $\begin{array}{l}\text { Articles in Chinese; summaries and table } \\
\text { of contents in English }\end{array}$ & $\begin{array}{l}\text { Free abstract; } \\
\text { paywalled } \\
\text { articles }\end{array}$ \\
\hline Chinese Journal of Hepatology & None, none & Yes & $\begin{array}{l}\text { Articles in Chinese; abstracts and table } \\
\text { of contents in Chinese and English }\end{array}$ & $\begin{array}{l}\text { Free abstract; } \\
\text { paywalled } \\
\text { articles }\end{array}$ \\
\hline $\begin{array}{l}\text { Chinese Journal of Integrated Traditional } \\
\text { and Western Medicine } \rightarrow \text { new title: Chinese Journal } \\
\text { of Integrative Medicine }\end{array}$ & None, 1.346 & Yes & English & $\begin{array}{l}\text { Free abstract; } \\
\text { paywalled } \\
\text { articles }\end{array}$ \\
\hline Chinese Journal of Surgery & None, none & Yes & $\begin{array}{l}\text { Articles in Chinese; Some } \\
\text { articles from } 2001 \text { to } 2002 \text { in English }\end{array}$ & $\begin{array}{l}\text { Free abstract; } \\
\text { paywalled } \\
\text { articles }\end{array}$ \\
\hline Chinese Medical Journal & $0.561,1.596$ & Yes & English & Open access \\
\hline Hepatobiliary and Pancreatic Diseases International & None, 1.500 & Yes & English & $\begin{array}{l}\text { Free abstract; } \\
\text { paywalled } \\
\text { articles }\end{array}$ \\
\hline $\begin{array}{l}\text { Journal of Huazhong University of Science and Technology } \\
\text { [Medical Sciences] } \rightarrow \text { new title: Current Medical Science }\end{array}$ & None, 0.948 & No & English & $\begin{array}{l}\text { Free abstract; } \\
\text { paywalled } \\
\text { articles }\end{array}$ \\
\hline National Journal of Andrology & None, none & Yes & $\begin{array}{l}\text { Articles in Chinese; Abstracts and } \\
\text { table of contents in Chinese and English }\end{array}$ & $\begin{array}{l}\text { Free abstract; } \\
\text { paywalled } \\
\text { articles }\end{array}$ \\
\hline National Medical Journal of China & None, none & Yes & $\begin{array}{l}\text { Articles in Chinese; some articles } \\
\text { published in English }\end{array}$ & $\begin{array}{l}\text { Free abstract; } \\
\text { paywalled } \\
\text { articles }\end{array}$ \\
\hline World Journal of Gastroenterology & $3.318,3.300$ & Yes & English & Open access \\
\hline
\end{tabular}


authors have disclosed financial conflicts of interest...." [8]. Journals can also be removed (deselected) from MEDLINE if it discovers major changes in its "scientific quality or editorial process"; [9] however, review cycles for currently indexed journals are not disclosed.

In our study, there has been an improvement in the number of Chinese journals including research ethics and research integrity requirements as a contingency to manuscript submission and acceptance (compared to our initial study in 2008); however, we still found some MEDLINE-indexed journals falling short. Specifically, the distinction between informed consent for research study participation and informed consent for publication of case studies and images (with descriptive or identifying information) is generally not delineated by most journals in our study.

Case studies are generally unique presentations of one or two patients, not part of a committee-approved research study, and thus they lack the committeeapproved protocol and consent process. This said publication of such work can potentially pose privacy concerns and should require the consent of the patient if there is descriptive or identifying information with privacy risks. If these case studies involve organ donation and/or transplantation, it is vital that the patient/legal surrogate understand and consent to the procedure. Also, the organ source should always be stated in the manuscript (e.g., living donor, deceased donor, increased risk donor) [10]. Further, all such organs must be ethically sourced $[2,11]$ and this disclosed in the manuscript submission process [1].

As reported in our original study, these journals were chosen for analysis due to their history of publishing manuscripts about organ donation and transplantation-ethically complex topics (especially in China). It is also important to note that organ donation is an altruistic social good that promotes the goals of medicine, thus is it unfortunate that only 2 of 11 (18.2\%) journals in our analysis provide their full-text articles free to scientists, physicians, and the lay public via open access. Knowing that organ donation consistently falls short of need [12] yet is linked to lifesaving transplant technology, it is vital that research and education articles on these topics be readily accessible to physicians, scientists, and society at large, in order to advance science and promote donation.

Since our original work in 2008, other researchers have also called for high ethical publication standards for manuscripts pertaining to organ donation and transplantation [13, 14]. Importantly, some journals such as the American Journal of Transplantation [15], Journal of Clinical Investigation [16], and Journal of Heart and Lung Transplantation [17] refuse to publish articles if the data are derived from an executed prisoner. The journals Transplantation, as well as Transplantation
Direct, both published by The Transplantation Society (www.TTS.org), require that all procedures and studies described "have involved no illegal commercial transactions, the use of organs or other material from executed prisoners, or other unethical practices in obtaining donor organs" $[18,19]$. The Transplantation Society is a global professional society of health care workers (e.g., physicians, surgeons, nurses, social workers, ethicists) who work in organ donation and transplant. In this current study of Chinese journals, we found none with a similar explicit ethics requirement on this topic, despite our call for this in our original study [1].

\section{Conclusions}

While Chinese journals avoid addressing the ethical complexity of publishing works pertaining to donation and transplant, they have, in general, responded to our call to heighten their general ethical requirements relating to research ethics committee approval, research informed consent, authorship criteria, conflict of interest, duplicate publishing, and data integrity. Some questions remain: (1) Why are Chinese journals refusing to employ a rule that excludes data sourced from unethical donation and transplant practices? Indeed, such a rule requires journals to have the moral courage to overtly identify and describe unethical donation and transplant practices. This could be difficult if transplant hospitals, procurement services, research funds, and/or publishers are sponsored or supported by the Chinese government, as it has been known to be complicit in such unethical behaviors [11]. While most of the journals in this analysis are not open access, even with low impact factors they are nonetheless not obscure, as 9 of 11 are MEDLINEindexed, making their content findable and potentially accessible [usable]. This is one of the reasons why excluding unethical data from journals is vital.

Noting that most of the Chinese journals in our study did improve their general publishing ethics requirement, an important question arises: Are these journals upholding their newly adopted general publishing ethics requirements or operating with business as usual? We pose a future study to address this. Lastly, we noted that two journals (Chinese Medical Journal and ACTA Academiae Medicinae Sinicae) had lowered their publishing standards on some ethical components. Perhaps this was an accidental oversight when they revised their publishing policies as it seems ethically counterproductive to remove requirements of conflict of interest disclosure and informed consent for descriptive/identifying information, as well as forbidding of duplicate publishing. If these requirements are truly eliminated, one wonders if the journal permits publishing that violates these concepts. Our future study will explore this. 


\section{Acknowledgements}

The authors gratefully thank Springer Nature for the APC fee waiver which allows us to publish our work as Open Access for the benefit of researchers and society.

\section{Authors' contributions}

Both authors contributed to the design of the study, as well as data collection and analysis, and the writing of the manuscript. Both authors read and approved the final manuscript.

\section{Funding}

No direct funding was received for this project.

\section{Availability of data and materials}

The data that support the findings of this study are available from the authors upon reasonable request.

\section{Ethics approval and consent to participate}

Exempt from IRB/REC review: no human subjects.

\section{Consent for publication}

No human subjects; not applicable.

\section{Competing interests}

The authors declare that they have no competing interests.

\section{Author details}

'Luxembourg Agency for Research Integrity (LARI), 6, avenue des Hauts-Fourneaux, L-4362 Esch-sur-Alzette, Luxembourg. ${ }^{2}$ Bond University Medical Program, University Drive, Gold Coast, Queensland, Australia. ${ }^{3}$ Department of Vascular Surgery, University of lowa Hospital and Clinic, 200 Hawkins Drive, lowa City, IA 52242, USA.

Received: 12 June 2019 Accepted: 6 August 2019

Published online: 02 September 2019

\section{References}

1. Bramstedt KA, China XJ. A case study regarding transplant publishing issues. J Infor Ethics. 2008;17(2):12-22. https://doi.org/10.3172/JIE.17.2.12.

2. Matas D, Kilgour D. Bloody Harvest: Revised Report into Allegations of Organ Harvesting of Falun Gong Practitioners in China 2007. organharvestinvestigation.net/report0701/report20070131-eng.pdf. Accessed 19 Feb 2018.

3. International Committee of Medical Journal Editors. Recommendations for the conduct, reporting, editing, and publication of scholarly work in medical journals. 2107. http://www.icmje.org/icmje-recommendations.pdf. Accessed 10 Dec 2018.

4. Amos KA. The ethics of scholarly publishing: exploring differences in plagiarism and duplicate publication across nations. J Med Libr Assoc. 2014;102(2):87-91. https://doi.org/10.3163/1536-5050.102.2.005.

5. Clarivate Analytics. 2018 journal citation reports. London: Clarivate Analytics; 2012.

6. US National Library of Medicine. NLM Catalog: journals referenced in the NCBI databases. Undated. https://www.ncbi.nlm.nih.gov/nlmcatalog/ journals. Accessed 10 Dec 2018.

7. National Journal of Andrology Editorial Office. Instructions for the submission of the National Journal of andrology. 2012. http://www.nkxb. cbpt.cnki.net/WKB2/WebPublication/wkTextContent.aspx?navigation ContentID=98b47930-5e45-4f40-8d24-47949651169e\&mid=nkxb. Accessed 10 Aug 2019.

8. US National Library of Medicine. Fact sheet MEDLINE ${ }^{\circledast}$ journal selection. 2018 https://www.nlm.nih.gov/lstrc/jsel.html. Accessed 19 Feb 2019.

9. US National Library of Medicine. FAQ: Journal Selection for MEDLINE ${ }^{\circledast}$ Indexing at NLM. 2018. https://www.nlm.nih.gov/Istrc/j_sel_faq.html\#a12. Accessed 19 Feb 2019.

10. Seem DL, Lee, I, Umscheid CA, Kuehnert MJ. United States Public Health Service. PHS Guideline for Reducing Human Immunodeficiency Virus, Hepatitis B Virus, and Hepatitis C Virus Transmission Through Organ Transplantation. Pub Health Rep. 2013;128(4):247-343. doi: 10.1177\%2 F003335491312800403

11. Rogers WA, Trey T, Singh MF, Fiatarone SM, Bridgett M, Bramstedt KA, Lavee J. Smoke and mirrors: unanswered questions and misleading statements obscure the truth about organ sources in China. J Med Ethics. 2016;42(8): 552-3. https://doi.org/10.1136/medethics-2016-103533.

12. Koons B, Smeltzer SC. The patient experience of waiting on the deceased donor kidney transplant list while receiving dialysis. Nephrol Nurs J. 2018; 45(4):349-55.

13. Valapour M, Paulson HA. Strengthening protections for human subjects: proposed restrictions on the publication of transplant research involving prisoners. Liver Transpl. 2013;19(4):362. https://doi.org/10.1002/lt.23603.

14. Rogers W, Robertson MP, Ballantyne A, Blakely B, Catsanos R, Clay-Williams $\mathrm{R}$, et al. Compliance with ethical standards in the reporting of donor sources and ethics review in peer-reviewed publications involving organ transplantation in China: a scoping review. BMJ Open. 2019;9:e024473. https://doi.org/10.1136/bmjopen-2018-024473.

15. American Journal of Transplantation. Instructions to authors. 2017. https:// wol-prod-cdn.literatumonline.com/pb-assets/assets/16006143/AJT_ Instructions_to_Authors-1530282835830.pdf. Accessed 19 Feb 2019.

16. Caplan AL, Rockman HA, Turka LA. Editorial position on publishing articles on human organ transplantation. J Clin Invest. 2012;122(1):2-2. https://doi. org/10.1172/JCl61904.

17. Elsevier. The Journal of Health and Lung Transplantation Author Information. 2019. https://www.jhltonline.org/content/authorinfo. Accessed 19 Feb 2019.

18. Transplantation. Instructions for Authors. 2017. http://edmgr.ovid.com/tpa/ accounts/ifauth.pdf. Accessed 19 Feb 2019.

19. Transplantation Direct. Instructions for authors. 2017. http://edmgr.ovid. com/txd/accounts/Transplantation_Direct_Instructions_for_Authors_2017. pdf. Accessed 19 Feb 2019.

\section{Publisher's Note}

Springer Nature remains neutral with regard to jurisdictional claims in published maps and institutional affiliations.
Ready to submit your research? Choose BMC and benefit from:

- fast, convenient online submission

- thorough peer review by experienced researchers in your field

- rapid publication on acceptance

- support for research data, including large and complex data types

- gold Open Access which fosters wider collaboration and increased citations

- maximum visibility for your research: over $100 \mathrm{M}$ website views per year

At BMC, research is always in progress.

Learn more biomedcentral.com/submissions 